Article

\title{
Efficient Regeneration of Hedychium coronarium through Protocorm-Like Bodies
}

\author{
Xiu Hu ${ }^{1}$, Jiachuan Tan ${ }^{1}$, Jianjun Chen ${ }^{2, *} \mathbb{D}$, Yongquan $\mathrm{Li}^{1, *}$ and Jiaqi Huang ${ }^{1}$ \\ 1 Department of Horticulture and Landscape Architecture, Zhongkai University of Agriculture \\ and Engineering, Guangzhou 510225, China; xiuhu0938@zhku.edu.cn (X.H.); tanjiachuan@zhku.edu.cn (J.T.); \\ huangjiaqi@zhku.edu.cn (J.H.) \\ 2 Department of Environmental Horticulture and Mid-Florida Research and Education Center, \\ Institute of Food and Agricultural Sciences, University of Florida, Apopka, FL 32703, USA \\ * Correspondence: jjchen@ufl.edu (J.C.); yongquanli@zhku.edu.cn (Y.L.)
}

Received: 1 July 2020; Accepted: 22 July 2020; Published: 24 July 2020

\begin{abstract}
Hedychium coronarium J. Koenig is a multipurpose plant with significant economic value, but it has been overexploited and listed as a vulnerable, near threatened or endangered species. In vitro culture methods have been used for propagating disease-free propagules for its conservation and production. However, explant contamination has been a bottleneck in in vitro propagation due to the use of rhizomes as the explant source. Plants in the family Zingiberaceae have pseudostems that support inflorescences, while rhizomes are considered true stems. The present study, for the first time, reported that the pseudostem bears nodes and vegetative buds and could actually be true stems. The evaluation of different sources of explants showed that mature node explants derived from the stem were the most suitable ones for in vitro culture because of the lowest contamination and the highest bud break rates. Culture of mature node explants on MS medium supplemented with 13.32, 17.76, and 22.20 $\mu \mathrm{M}$ 6-benzylaminopurine (BA), each in combination with $9.08 \mu \mathrm{M}$ thidiazurin (TDZ) and $0.05 \mu \mathrm{M} \alpha$-naphthaleneacetic acid (NAA) induced the conversion of buds to micro-rhizomes in six weeks. More than $96 \%$ of the micro-rhizomes cultured on MS medium supplemented with $17.76 \mu \mathrm{M}$ BA, $6.81 \mu \mathrm{M}$ TDZ, and $2.46 \mu \mathrm{M}$ indole-3-butyric acid (IBA) were converted to globular-shaped clumps with protocorm-like bodies (PLBs). Further culture of a piece of the clumps induced more than 15 adventitious shoots. Adventitious roots were produced at the base of adventitious shoots, and plantlets were readily transplanted to a substrate for acclimatization in a shaded greenhouse. The survival rate of the plants in the greenhouse was up to $90 \%$. Plants grew vigorously, and there were no off-types from the regenerated 11,100 plants. Our study also, for the first time, shows that $H$. coronarium can be regenerated via PLBs, which may represent a new way of the in vitro propagation of $H$. coronarium. The established protocol could be used for the increased propagation of $H$. coronarium for conservation or commercial production.
\end{abstract}

Keywords: Hedychium; medicinal plants; ornamental plants; protocorm-like bodies (PLBs); pseudostem; rhizome; shoot culture; stem of white ginger lily; TDZ

\section{Introduction}

Hedychium J. Koenig, a member of the family Zingiberaceae, consists of about 50 species [1] native to Himalayan regions [2], which are rhizomatous perennials, growing to about 1 to $2 \mathrm{~m}$. They are economically important, multipurpose plants and are cultivated for their sweet-scent flowers and attractive green foliage [3]. Hedychium plants are also used as raw materials for isolating volatile oils, diterpenes, and flavonoids [4] and for manufacturing paper and perfume [5,6]. Additionally, Hedychium species are medicinal plants, and bioactive compounds extracted from leaves and rhizomes 
have antibacterial, antifungal, and anti-inflammatory activities [7]. Due to their multiple uses, some Hedychium species, such as H. coronarium, have been overexploited and listed as vulnerable, near threatened or endangered in different regions [7-9]. Traditionally, Hedychium species are propagated by the seed or division of rhizome; however, few seeds are produced per inflorescence, and seed propagation may result in genetic variation in progenies. Thus, rhizomes are the main organ used for propagation. Overexploitation may cause limitation in rhizome availability, and rhizomes may carry diseases and pests affecting conservation or commercial production. Micropropagation is considered the most effective method for rapid increase of disease-free propagules on a year-round basis [10].

Micropropagation includes shoot culture and regeneration via organogenesis, somatic embryogenesis, and protocorm-like-bodies (PLBs) [11,12]. Shoot culture is the induction of axillary shoots from existing meristems, which is considered a reliable method for producing genetically identical plants without the occurrence of somaclonal variation $[13,14]$. Other pathways for in vitro propagating plants with little somaclonal variation are direct shoot organogenesis, direct somatic embryogenesis, and direct formation of protocorm like bodies, i.e., a regeneration process without passage through a callus phase $[11,14,15]$. Thus, these pathways are the most desired ways of propagating valuable genetic resources for plant conservation or production as regenerated plants are generally true to type [11].

Plant regeneration via PLBs is a unique way of producing plantlets [16]. The term of PLBs was first coined by Morel [17] when the shoot apex of Cymbidium was cultured for producing virus-free plants, where protocorms were formed from apical meristems rather than from seeds. The usage of the PLB had been initially restricted to in vitro culture of orchids [18] but has been extended to other crops over the last 40 years [19-25]. In plants other than orchids, PLBs are generally induced directly from shoot tips, flower stalk buds, root tips, nodes, and leaf segments [26]. Differentiation in epidermal cells results in the formation of compact regions that are composed of meristemoids $[24,27,28]$. Further cell division produces anterior smaller cells that give rise to the shoot pole of PLBs [28]. The first leaf appears from the shoot pole of PLB, and root is produced at the base of shoot. An advantage of regeneration through PLBs is that a large number of plantlets can be produced, thus enhancing propagation efficiency. Furthermore, the regeneration is generally not involved in the callus phase, so the possibility for the occurrence in somaclonal variation is not common [29].

The micropropagation of Zingiberaceae plants like H. coronarium has been severely challenged by the lack of appropriate explants [30,31]. This is because the shoots are pseudostems, and the true stems are rhizomes [32]. Rhizomes are generally considered the only source of existing meristems for shoot culture. The rhizome, however, is an underground organ with a succulent texture. Tedious disinfection procedures must be performed, including washing explants for a long time, using different types of disinfectants or different combinations of disinfectants [33]. It is extremely difficult to disinfect the rhizomes, and contamination has been a major problem in in vitro shoot culture of H. coronarium [34]. In addition to shoot culture, few reports have documented regeneration of $H$. coronarium through callus mediated somatic embryogenesis $[29,35]$ and an unnamed pathway for regeneration of $H$. coronarium [36]. Thus far, there has been no report on regeneration of H. coronarium through direct somatic embryogenesis or direct formation of PLBs.

The objectives of this study were to explore alternative explant sources for substantially reducing contamination during the in vitro culture of H. coronarium and develop a regeneration method for efficient propagation of this species.

\section{Materials and Methods}

\subsection{Plant Material}

A new cultivar H. coronarium Hanyue was used in this study. It was officially registered by the Seed Administration Department of Guangdong Province, China. Compared to the traditional cut-flower cultivars of H. coronarium, 'Hanyue' has colorful flower with a more pleasant scent and a shorter 
and stronger pseudostem. It flowers year-round, thus producing more cut flowers than the traditional cultivars of H. coronarium. 'Hanyue' has gained increasing popularity and is recognized as a promising cultivar for partially replacing the traditional Hedychium cut-flower cultivars. 'Hanyue' plants were grown at the experimental station of Zhongkai University of Agriculture and Engineering, Guangzhou city, Guangdong Province, China.

Pseudostems of 'Hanyue' at two stages: one with senescing inflorescence and the other without the appearance of inflorescence, were dissected by gradually removing all the leaves. We realized that the pseudostems with senesced inflorescence had nodes and internodes, and each node had a vegetative bud. The same was true for pseudostems without inflorescence except that the buds in the tip 3-4 nodes were either invisible or underdeveloped. We herein called the pseudostem as a stem.

Four types of explants were prepared from 'Hanyue' plants: (a) Mature node explants: Leaves of mature stems at anthesis, a height of $80 \mathrm{~cm}$ with $8-10$ nodes (Figure 1A-1) were stripped and cut to a length $3-4 \mathrm{~cm}$, but the innermost leaf layer was kept for protecting hidden buds from contamination and/or injury by disinfectants (Figure 1A-2). The stem pieces were thoroughly sprayed with $75 \%$ ethanol $(v / v)$ once and placed in a laminar flow hood. (b) Young node explants: Young stems prior to anthesis were tender with a height about $60 \mathrm{~cm}, 7-8$ nodes (Figure 1B-1). The stem pieces were prepared in the same way as the mature node explants. (c) Mature eye explants: Mature rhizomes were excised from stock plants and washed thoroughly with running tap water for $30 \mathrm{~min}$. Roots and outer scales were removed. Rhizomes were washed with distilled water and sprayed thoroughly with $75 \%$ ethanol once (Figure 1C) in laminar flow hood. Using a dissection knife, a single eye of $8 \times 8 \mathrm{~mm}$ was taken from each mature rhizome (Figure 1C-1). (d) Young rhizome tip explants: Rhizomes with new growth (Figure 1D-1) were washed and sprayed with $75 \%$ ethanol. The young and new portion of the rhizome was excised (Figure 1D-2) as young rhizome tip explants.

In a laminar air flow hood, the mature and young stem pieces as well as mature eye and young rhizome shoot explants were disinfected one more time with $75 \%$ ethanol for $1 \mathrm{~min}$, followed by disinfection with $0.1 \%(w / v)$ of $\mathrm{HgCl}_{2}$. The explants were immersed in the $\mathrm{HgCl}_{2}$ solution for 5,10 , and $15 \mathrm{~min}$, respectively and then rinsing with sterile distilled water 6 times. The innermost leaf layer was removed from the mature stem pieces (Figure 1A-3), exposing the bud (Figure 1A-4), which was cut to about $1.5 \mathrm{~cm}$ as single node mature stem explant. Similarly, the innermost leaf layer of the young stem piece was removed, single node young stem explants were produced (Figure 1B-2,3), but the stem tip (Figure 1B-4) was not used as the buds were either invisible or underdeveloped. For each explant type, there were 45 per treatment.

\subsection{Evaluation of Explants}

The disinfected four types of explants were cultured on MS medium [37] supplemented with $17.76 \mu \mathrm{M}$ 6-benzylaminopurine (BA), $4.54 \mu \mathrm{M}$ thidiazurin (TDZ), and $0.05 \mu \mathrm{M} \alpha$-naphthaleneacetic acid (NAA). The combination of growth regulators and their concentrations were chosen based on our preliminary experimental results. There was one explant per $250 \mathrm{~mL}$ glass culture vessel (Shanghai Zeshine Equipment Co., Shanghai, China), each vessel had the manufacturer supplied cap. The experiment was arranged as a randomized complete block design (RCBD) with three blocks (replications), 15 vessels per block. The vessels were maintained in a culture room under a 12-h photoperiod provided by cool-white fluorescent lamps (Shenzhen TILO Technology Co. Ltd., Shenzhen, China) with a photon flux density of $50 \mu \mathrm{mol} \mathrm{m}{ }^{-2} \mathrm{~s}^{-1}$ at each level of shelfs and temperature of $25 \pm 2{ }^{\circ} \mathrm{C}$. All cultures were monitored three times a week for contamination. After four weeks, explants with bacterial and fungal contaminations and bud break were recorded. The frequencies of bud break or contamination were calculated as the numbers of explants in a block with bud break or contamination divided by 15 (15 vessels per block $) \times 100$. 

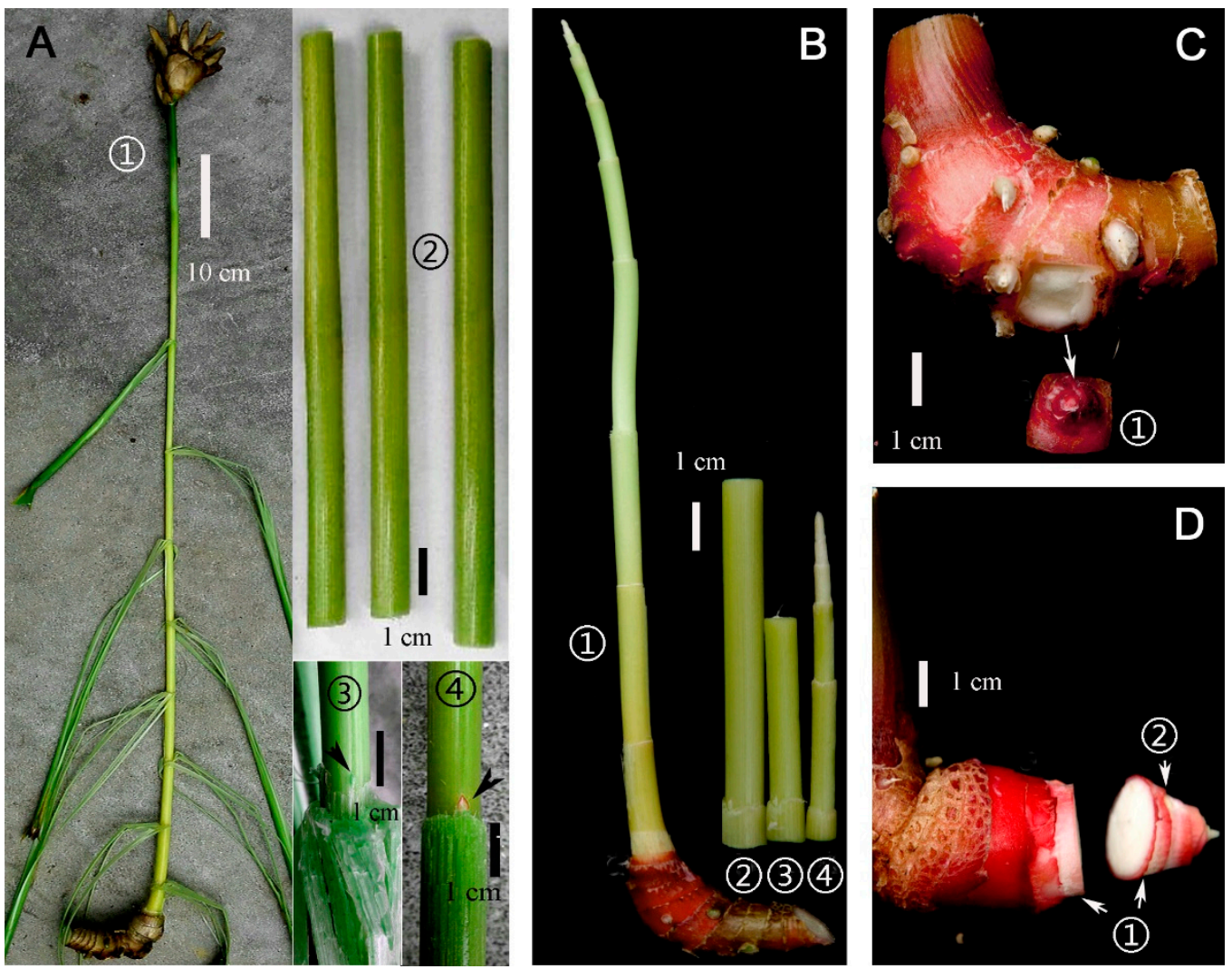

Figure 1. Four types of explants were prepared from stem or rhizomes of Hedychium coronarium 'Hanyue'. (A-1) Mature stem at anthesis; (A-2) after stripping out-layer leaves, the stem was cut to $3-4 \mathrm{~cm}$ in length and were sprayed thoroughly with $75 \%$ ethanol $(v / v)$ once in a laminar air flow hood; (A-3) the most inner layer was stripped; and (A-4) single node explant with a bud or eye (arrow) was obtained. (B-1) Young stems prior to anthesis; the stem was cut to small segments and sprayed thoroughly with $75 \%$ ethanol once in a laminar air flow hood. The most inner layer was stripped, and single node explants were harvested (B-2 and B-3), but the tip of stem (B-4) was not used as buds were either invisible or underdeveloped. C. Mature rhizome was washed and sprayed with $75 \%$ ethanol once. Single eye explant was produced by cutting single eye out of the disinfected mature rhizome (C-1). D. Rhizomes with new growth (D-1) were cleaned and sprayed with $75 \%$ ethanol once. Young and fresh portion of rhizome was cut from the mature portion (D-2) and used as young rhizome tip explants.

\subsection{Induction of Micro-Rhizomes from Mature Node Explants}

Mature node explants were cultured on MS medium supplemented with 13.32, 17.76, and $22.20 \mu \mathrm{M}$ BA in a factorial combination with $0,0.91,9.08$, and $19.16 \mu \mathrm{M} \mathrm{TDZ}$; each of the combination had $0.05 \mu \mathrm{M}$ NAA. There was one mature node explant per $250 \mathrm{~mL}$ culture vessel. The experiment was set up as a RCBD with three blocks, 15 vessels per block. The node explants were cultured under the onditions mentioned above. After six weeks of culture, the number of micro-rhizomes and their diameters as well as adventitious shoots if any were recorded.

\subsection{Conversion of Micro-Rhizomes to PLB Clumps}

Mature node explants were cultured on MS medium containing $17.76 \mu \mathrm{M}$ BA, $9.08 \mu \mathrm{M}$ TDZ, and $0.05 \mu \mathrm{M}$ NAA to induce enough micro-rhizomes. The micro-rhizomes were cultured on MS medium supplemented with $0,2.27,4.54,6.81$, and $9.08 \mu \mathrm{M} \mathrm{TDZ}$, each in combination with $17.76 \mu \mathrm{M}$ BA and $2.46 \mu \mathrm{M}$ indole-3-butyric acid (IBA). One micro-rhizome was inoculated per culture vessel. The experiment was a RCBD with three blocks, 15 vessels per block. The vessels were cultured under 
the same conditions mentioned above. After eight weeks of culture, micro-rhizomes were converted to globular-shaped clumps bearing multiple tuber-shaped bodies, which resembled PLBs. The frequency of micro-rhizome conversion to PLB clump, PLB clump diameter, the number of PLBs per clump, and shoot number if any and their height were recorded.

\subsection{Induction of Adventitious Shoots from PLBs}

To induce shoots, PLB clumps induced from $17.76 \mu \mathrm{M}$ BA, $6.81 \mu \mathrm{M}$ TDZ, and $2.46 \mu \mathrm{M}$ IBA were cut into four pieces, each about $5 \mathrm{~mm} \times 5 \mathrm{~mm}$ in size and cultured on MS medium containing $17.76 \mu \mathrm{M}$ BA with $0,0.54,2.69$, and $5.37 \mu \mathrm{M}$ NAA, respectively. In addition to adventitious shoot induction, this step also tested if more PLBs could be produced from clump pieces and if such action could increase propagation efficiency. Again, there was one explant per culture vessel. The experiment was a RCBD with three blocks, 12 vessels per block. The culture was maintained in the aforementioned conditions. After six weeks of culture, shoot numbers, shoot base diameter, shoot height, and root numbers were recorded. Additionally, the multiplication rate was calculated as the number of shoots with roots (plantlets) produced from a single node explant at the end of a multiplication cycle (i.e., 20 weeks).

\subsection{Rooting, Transplanting, and Acclimatization}

Roots spontaneously occurred from induced shoots. Thus, shoots with roots (plantlets) were transplanted to containers filled with a substrate comprised of autoclaved soil, sand, and farmyard manure in 1:1:1 ratio based on the volume in a shaded greenhouse. The photosynthetically active radiation ranged from 300 to $400 \mu \mathrm{mol} \mathrm{m} \mathrm{m}^{-2} \mathrm{~s}^{-1}$. To maintain a high relative humidity, all containers were initially covered with polythene film and watered as needed for initial acclimatization. After two weeks, polythene bags were removed, and plants were irrigated with tap water and fertilized with a water-soluble fertilizer ( $\left.\mathrm{N}-\mathrm{P}_{2} \mathrm{O}_{5}-\mathrm{K}_{2} \mathrm{O} ; 20-20-20\right)$ (Qingdao Sonef Chemical Co. Ltd., Qingdao, China) solution with a nitrogen at $50 \mathrm{mg} \mathrm{L}^{-1}$. A total of 12,000 plantlets were transplanted into the substrate and acclimatized in the greenhouse. All the dead plantlets were counted after additional one month of growth in the greenhouse, and survival rates were calculated.

\subsection{Data Analysis}

Collected data were subjected to analysis of variance (ANOVA) using SPSS version 20.0 (IBM, Corp., Armonk, NY, USA). If significant differences occurred among treatments, means were separated by Fisher's Least Significant Differences (LSD) at $p<0.05$ levels. Data were presented as mean \pm standard error.

\section{Results}

\subsection{Contamination and Bud Break of Four Types of Explants}

Explant contamination (both bacteria and fungi) was a major problem, ranging from $4.44 \%$ to $100 \%$ depending on explant types and durations of disinfection (Table 1). Increasing disinfection time with $\mathrm{HgCl}_{2}$ from 5 min to 10 min significantly decreased the contamination rates regardless of explant types. There were no significant differences between 10 and $15 \mathrm{~min}$ except that a 15-min disinfection of mature eye explants significantly decreased in contamination rate compared to the $10 \mathrm{~min}$. 
Table 1. Availability of four types of explants derived from H. coronarium 'Hanyue' cultured on Murashige and Skoog medium for four weeks and their contamination frequency and bud break rates.

\begin{tabular}{|c|c|c|c|c|}
\hline Explant Type & No. of Explant Per Source * & $\begin{array}{l}\text { Min. of Disinfection } \\
\text { with } 0.1 \% \mathrm{HgCl}_{2}\end{array}$ & $\begin{array}{l}\text { Contamination } \\
\text { Frequency (\%) }\end{array}$ & $\begin{array}{c}\text { Bud Break } \\
\text { Frequency }(\%)\end{array}$ \\
\hline Mature node explant & $8-10$ & $\begin{array}{c}5 \\
10 \\
15\end{array}$ & $\begin{array}{c}28.89 \pm 2.22 \mathrm{gh} \\
8.89 \pm 2.22 \mathrm{i} \\
4.44 \pm 2.22 \mathrm{ijkl}\end{array}$ & $\begin{array}{l}68.89 \pm 2.22 \mathrm{c} \\
91.11 \pm 2.22 \mathrm{~b} \\
95.56 \pm 2.22 \mathrm{a}\end{array}$ \\
\hline Young node explant & $7-8$ & $\begin{array}{c}5 \\
10 \\
15\end{array}$ & $\begin{array}{c}33.33 \pm 0.00 \mathrm{~g} \\
8.89 \pm 4.44 \mathrm{ij} \\
6.67 \pm 3.85 \mathrm{ijk}\end{array}$ & $\begin{array}{c}6.67 \pm 3.85 \mathrm{fg} \\
6.67 \pm 3.85 \mathrm{fgh} \\
0 \pm 0.00 \mathrm{fghij}\end{array}$ \\
\hline Mature eye explant & $3-5$ & $\begin{array}{c}5 \\
10 \\
15\end{array}$ & $\begin{array}{c}100 \pm 0.00 \mathrm{a} \\
82.22 \pm 2.22 \mathrm{c} \\
48.89 \pm 2.22 \mathrm{def}\end{array}$ & $\begin{array}{c}0 \pm 0.00 \mathrm{fghijkl} \\
8.89 \pm 2.22 \mathrm{f} \\
6.67 \pm 3.85 \mathrm{fghi}\end{array}$ \\
\hline Young rhizome tip explants & $1-3$ & $\begin{array}{c}5 \\
10 \\
15\end{array}$ & $\begin{array}{c}93.33 \pm 3.85 \mathrm{~b} \\
57.78 \pm 2.22 \mathrm{de} \\
60 \pm 3.85 \mathrm{~d}\end{array}$ & $\begin{array}{c}0 \pm 0.00 \text { fghijk } \\
26.67 \pm 3.85 \mathrm{~d} \\
26.67 \pm 6.67 \mathrm{de}\end{array}$ \\
\hline
\end{tabular}

Note: ${ }^{*}$ the number of explants was based on each stem or each rhizome. For each explant type, there were 45 explants per treatment. Data were mean \pm standard error (S.E.) with $n=3$. Means followed by different letters within a column indicate significant differences at $p<0.05$ based on Fisher's least significant difference (LSD).

Bud break frequencies of mature node explants ranged from $68.89 \%$ to $95.56 \%$ when disinfected from 5 to $15 \mathrm{~min}$ (Table 1). Both young rhizome tips and mature eye explants had the lowest bud break frequencies, varying from $0 \%$ to $8.89 \%$. No bud break occurred in young rhizome tip explants after 15 min disinfection or the mature rhizome eye explants disinfected for $5 \mathrm{~min}$.

A comparison of the availability of explant sources indicated that more mature node explants were attained from mature stems, ranging from 8 to 10 per stem compared to one to three explants from the young rhizome, and three to five from the mature rhizome. About seven to eight node explants could be taken from the young stem, but buds in the stem tip were either invisible or underdeveloped. Thus, the usable explants were those in the base of stem, ranging from three to four.

\subsection{Induction of Micro-Rhizomes from Mature Stem Explants}

Disinfected mature stem explants (Figure 2A) were cultured on MS medium containing $0.05 \mu \mathrm{M}$ NAA with different concentrations of BA and TDZ (Table 2). Bud break occurred after one week (Figure 2B) and fully expanded in two weeks (Figure 2C). The bud differentiated and became pinkish with scale (Figure 2D) and then converted to a micro-rhizome (Figure 2E) in four to five weeks. The micro-rhizome was covered by either green or pink scales. Data collected from six weeks of culture showed that the frequencies of micro-rhizome formation varied from $62.22 \%$ to $100 \%$ depending on treatments (Table 2). The frequencies increased with the increased concentrations of BA when there was no addition of TDZ or with $0.91 \mu \mathrm{M}$ TDZ. Micro-rhizome formation frequencies reached $100 \%$ six weeks after culturing on medium containing either of three levels of BA with $9.08 \mu \mathrm{M}$ TDZ. However, when the TDZ concentration increased to $19.16 \mu \mathrm{M}$, increasing concentrations of BA caused decreased micro-rhizomes formation frequencies. The diameters of the micro-rhizomes induced by three levels of BA with $9.08 \mu \mathrm{M}$ TDZ or 17.76 and $22.20 \mu \mathrm{M}$ BA with $0.91 \mu \mathrm{M}$ TDZ were significantly larger, over $4 \mathrm{~mm}$, than those induced by the others. Additionally, multiple shoots occurred from micro-rhizomes induced from medium containing three levels of BA respectively with $19.16 \mu \mathrm{M}$ TDZ and $0.05 \mu \mathrm{M}$ NAA, but there was no shoot formation from mature explants cultured on the other concentrations of BA and TDZ (Table 2). 

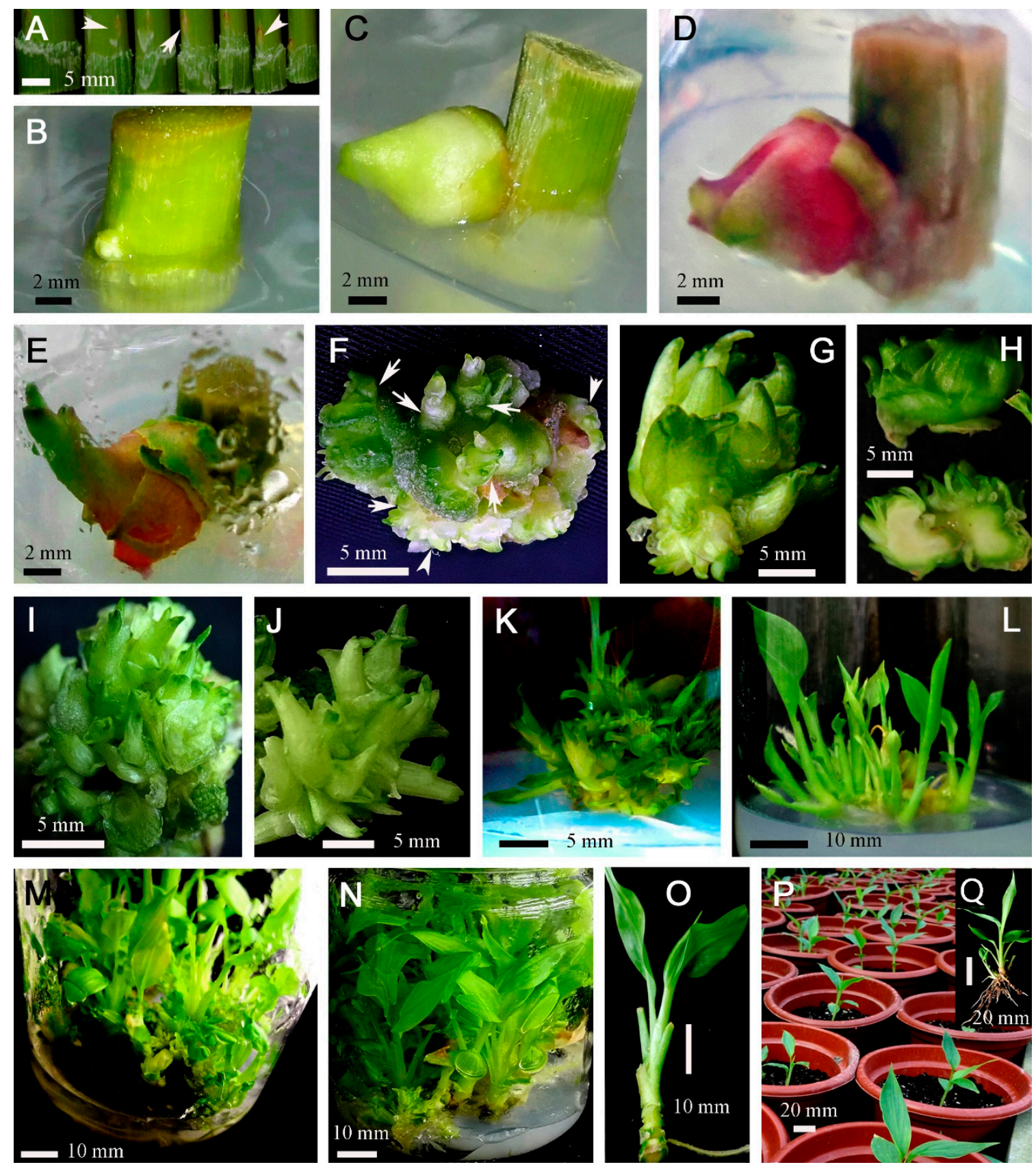

Figure 2. Regeneration of $H$. coronarium 'Hanyue' through protocorm-like bodies (PLBs). (A) Single node explants were derived from mature flower stem, and the pinkish dot was the bud (arrow). (B) The bud started expansion in one week and became fully expanded in two weeks (C). (D) The expanded bud became pinkish with scale in three weeks and then elongated with more scales resembling a micro-rhizome in four to five weeks (E). Subculture of micro-rhizome resulted in the conversion of micro-rhizome to a globular-shaped clump bearing multiple tube-shaped bodies called PLBs (arrows) (F), The development of PLBs formed multiple shoot primordia (G). The globular-shaped clump was cut to four pieces as explants $(\mathbf{H})$, which were cultured on MS medium, and more PLBs were formed from each clump piece (I). Subsequently, multiple shoot primordia appeared and multiple shoot tips formed from clump piece (J). Multiple shoot tips with leaf appearance (K). Adventitious shoots in culture vessel $(\mathbf{L}, \mathbf{M})$. (N) Shoots grew vigorously in culture vessel. (O) Shoot with roots were excised. (P) Plantlets were transplanted to containers filled with a substrate and grown in a shaded greenhouse. They were well rooted after growing in the substrate for three weeks (insertion $\mathbf{Q}$ ). 
Table 2. Induction of micro-rhizomes from mature stem explants of H. coronarium 'Hanyue' after six weeks of culture on Murashige and Skoog medium supplemented with $0.05 \mu \mathrm{M} \alpha$-naphthaleneacetic acid (NAA) with different combinations of 6-benzylaminopurine (BA) and thidiazurin (TDZ).

\begin{tabular}{|c|c|c|c|c|}
\hline \multicolumn{2}{|c|}{ Combination of Growth Regulators } & \multirow{2}{*}{$\begin{array}{c}\text { Frequency of } \\
\text { Micro-Rhizome Induced (\%) }\end{array}$} & \multirow{2}{*}{$\begin{array}{l}\text { Micro-Rhizome } \\
\text { Diameter (mm) }\end{array}$} & \multirow{2}{*}{$\begin{array}{l}\text { No. of Shoots Per } \\
\text { Micro-Rhizome }\end{array}$} \\
\hline BA $(\mu \mathrm{M})$ & TDZ $(\mu \mathrm{M})$ & & & \\
\hline 13.32 & 0 & $68.89 \pm 2.22 \mathrm{hij}$ & $1.60 \pm 0.04 \mathrm{kl}$ & 0 \\
\hline 17.76 & 0 & $77.78 \pm 2.22 \mathrm{gh}$ & $1.71 \pm 0.06 \mathrm{k}$ & 0 \\
\hline 22.20 & 0 & $82.22 \pm 2.22 \mathrm{~g}$ & $2.11 \pm 0.06 j$ & 0 \\
\hline 13.32 & 0.91 & $91.11 \pm 2.22 \mathrm{f}$ & $3.89 \pm 0.06 \mathrm{f}$ & 0 \\
\hline 17.76 & 0.91 & $95.55 \pm 2.22 \mathrm{de}$ & $4.33 \pm 0.04 \mathrm{~d}$ & 0 \\
\hline 22.20 & 0.91 & $97.78 \pm 2.22 \mathrm{abcd}$ & $4.69 \pm 0.06 \mathrm{ab}$ & 0 \\
\hline 13.32 & 9.08 & $100.00 \pm 0.00 \mathrm{a}$ & $4.20 \pm 0.04 \mathrm{de}$ & 0 \\
\hline 17.76 & 9.08 & $100.00 \pm 0.00 \mathrm{ab}$ & $4.53 \pm 0.04 b c$ & 0 \\
\hline 22.20 & 9.08 & $100.00 \pm 0.00 \mathrm{abc}$ & $4.87 \pm 0.04 \mathrm{a}$ & 0 \\
\hline 13.32 & 19.16 & $71.11 \pm 2.22 \mathrm{hi}$ & $2.93 \pm 0.04 \mathrm{~g}$ & 4.2 \\
\hline 17.76 & 19.16 & $64.45 \pm 2.22 \mathrm{ijk}$ & $2.40 \pm 0.04 \mathrm{~h}$ & 5.0 \\
\hline 22.20 & 19.16 & $62.22 \pm 2.22 \mathrm{kl}$ & $2.33 \pm 0.17 \mathrm{hi}$ & 5.8 \\
\hline
\end{tabular}

Data were mean \pm standard error (S.E.) with $n=3$. Means followed by different letters within a column indicate significant differences at $p<0.05$ based on Fisher's LSD.

\subsection{Conversion of Micro-Rhizomes to Globular-Shaped Clumps with PLBs}

The micro-rhizome cultured on MS medium containing TDZ and IBA (Table 3) was converted to a globular-shaped clump bearing multiple tuber-shaped bodies (arrows) which resembled PLBs (Figure 2F) and the further development of PLBs resulted in the appearance of multiple shoot primordia (Figure 2G). With increasing concentrations of TDZ from 0 to $6.81 \mu \mathrm{M}$, the frequencies of micro-rhizome conversion to globular-shaped clumps increased from $12 \%$ to $96 \%$, clump sizes increased from $0.37 \mathrm{~cm}$ to $2.04 \mathrm{~cm}$, and numbers of PLBs per clump increased from 3.82 to 26.93 (Table 3). However, when the TDZ concentration was elevated to $9.08 \mu \mathrm{M}$, all the mentioned parameters decreased. Adventitious shoots were induced when there was no TDZ or TDZ at $2.27 \mu \mathrm{M}$, but no shoots occurred when TDZ concentrations ranged from 4.54 to $9.08 \mu \mathrm{M}$ (Table 3).

Table 3. The conversion of micro-rhizome to globular-shaped clump bearing PLBs after eight weeks of culture on Murashige and Skoog medium containing $17.76 \mu \mathrm{M}$ BA and $2.46 \mu \mathrm{M}$ indole-3-butyric acid (IBA) with different concentrations of TDZ, respectively along with adventitious shoot numbers and their height.

\begin{tabular}{ccccccc}
\hline TDZ $(\mu \mathrm{M})$ & IBA $(\mu \mathrm{M})$ & $\begin{array}{c}\text { PLB Clump } \\
\text { Conversion (\%) }\end{array}$ & $\begin{array}{c}\text { PLB Clump } \\
\text { Diameter }(\mathbf{c m})\end{array}$ & $\begin{array}{c}\text { No. of PLB } \\
\text { Per Clump }\end{array}$ & $\begin{array}{c}\text { Shoot No. } \\
\text { Per Clump }\end{array}$ & $\begin{array}{c}\text { Shoot } \\
\text { Height }(\mathbf{c m})\end{array}$ \\
\hline 0 & 2.46 & $12.00 \pm 0.02 \mathrm{~d}$ & $0.37 \pm 0.01 \mathrm{e}$ & $3.82 \pm 0.15 \mathrm{e}$ & $10.76 \pm 0.15 \mathrm{a}$ & $4.23 \pm 0.02 \mathrm{a}$ \\
2.27 & 2.46 & $60.00 \pm 0.02 \mathrm{c}$ & $0.87 \pm 0.01 \mathrm{~d}$ & $10.13 \pm 0.20 \mathrm{~d}$ & $3.04 \pm 0.10 \mathrm{~b}$ & $2.49 \pm 0.01 \mathrm{~b}$ \\
4.54 & 2.46 & $82.67 \pm 0.02 \mathrm{~b}$ & $1.65 \pm 0.02 \mathrm{c}$ & $20.11 \pm 0.18 \mathrm{~b}$ & $0.00 \mathrm{c}$ & $0.00 \mathrm{c}$ \\
6.81 & 2.46 & $96.00 \pm 0.02 \mathrm{a}$ & $2.04 \pm 0.01 \mathrm{a}$ & $26.93 \pm 0.12 \mathrm{a}$ & $0.00 \mathrm{c}$ & $0.00 \mathrm{c}$ \\
9.08 & 2.46 & $86.67 \pm 0.02 \mathrm{~b}$ & $1.77 \pm 0.02 \mathrm{~b}$ & $17.67 \pm 0.19 \mathrm{c}$ & $0.00 \mathrm{c}$ & $0.00 \mathrm{c}$ \\
\hline
\end{tabular}

Note: Data were mean \pm standard error (S.E.) with $n=3$. Means followed by different letters within a column indicate significant differences at $p<0.05$ based on Fisher's LSD.

\subsection{Shoot Induction from PLBs}

The globular-shaped clumps were cut into four pieces and cultured on MS medium containing different concentrations of NAA with $17.76 \mu \mathrm{M}$ BA. PLBs proliferated (Figure 2I), produced shoot tips (Figure 2J-K), adventitious shoots grew healthily (Figure 2L-N) and produced roots (Figure 2O). The highest numbers of adventitious shoots (15.75) occurred when a clump piece was cultured with 17.76 $\mu \mathrm{M}$ BA and $0.54 \mu \mathrm{M}$ NAA (Table 4). Shoot numbers induced from the other treatments were significantly lower, ranging from 7.61 to 13.64 . With increasing NAA concentration, the diameter of the shoot base increased from $1.76 \mathrm{~mm}$ to $3.46 \mathrm{~mm}$, whereas shoot heights decreased from $4.78 \mathrm{~cm}$ to $2.39 \mathrm{~cm}$. The adventitious shoots with a height about $3 \mathrm{~cm}$ started producing roots, and mean root 
numbers per shoot induced by $17.76 \mu \mathrm{M}$ BA with $0.54 \mu \mathrm{M}$ NAA were 2.81 compared to 1.58 to 2.53 from the other treatments. Based on the highest shoot number of 15.75, the multiplication rate of this established protocol could be as high as 63 shoots per mature node explant during a 20-week multiplication cycle.

Table 4. Induction of adventitious shoots from PLBs after six weeks of culture of a piece of clump on Murashige and Skoog medium supplemented with BA and NAA.

\begin{tabular}{cccccc}
\hline BA $(\mu \mathbf{M})$ & NAA $(\boldsymbol{\mu M})$ & Shoot No. & $\begin{array}{c}\text { Shoot Base Diameter of } \\
\text { Shoot Base }(\mathbf{m m})\end{array}$ & Shoot Height $(\mathbf{c m})$ & Root No. Per Shoot \\
\hline 17.76 & 0 & $7.61 \pm 0.13 \mathrm{~d}$ & $1.76 \pm 0.02 \mathrm{~d}$ & $4.78 \pm 0.02 \mathrm{a}$ & $1.59 \pm 0.01 \mathrm{c}$ \\
17.76 & 0.54 & $15.75 \pm 0.16 \mathrm{a}$ & $2.63 \pm 0.04 \mathrm{c}$ & $3.82 \pm 0.04 \mathrm{~b}$ & $2.81 \pm 0.02 \mathrm{a}$ \\
17.76 & 2.69 & $13.64 \pm 0.14 \mathrm{~b}$ & $2.98 \pm 0.02 \mathrm{~b}$ & $2.94 \pm 0.02 \mathrm{c}$ & $2.53 \pm 0.01 \mathrm{~b}$ \\
17.76 & 5.37 & $9.72 \pm 0.16 \mathrm{c}$ & $3.46 \pm 0.04 \mathrm{a}$ & $2.39 \pm 0.04 \mathrm{~d}$ & $1.58 \pm 0.02 \mathrm{c}$ \\
\hline
\end{tabular}

Note: Data were mean \pm standard error (S.E.) with $n=3$. Means followed by different letters within a column indicate significant differences at $p<0.05$ based on Fisher's LSD.

\subsection{Ex Vitro Rooting and Growth in Greenhouse Conditions}

Adventitious shoots with roots were excised (Figure 2O), and the plantlets were transplanted to a container substrate and grew in a shade greenhouse (Figure 2P). After one month of planting, more than $90 \%$ of the transplanted plantlets survived, and over 11,100 plants grew vigorously with healthy roots (Figure 2Q), of which no morphologically off-type plants were observed.

\section{Discussion}

This study is the first report showing that pseudostems of H. coronarium are true stems. They have nodes and buds (Figure 1A). Back in 1985, Criley stated that in Zingiberaceae, the leaves tend to be arranged distichously and their open leaf sheaths form a pseudostem through which the true stem elongates and produces terminal flowers (hypoxanthic flowering) [38]. It is apparent that this statement was largely ignored over the last 35 years by plant scientists in micropropagation of ginger family plants. Our study clearly showed that the flower stem of 'Hanyue' has 8 to 10 nodes, and each node has a bud at anthesis. Although the significance for the identification of pseudostem as a true stem in a member of the family Zingiberaceae is unclear at this time, it has certainly improved our success in micropropagation of H. coronarium.

We compared four types of explants and found that the mature flower stem was the most suitable source for producing explants. First, the stem has several layers of leaf sheath. The buds are well protected by the sheath. Second, after removing the outer layers of leaves, the most inner layer of leaves was kept during the disinfection; as such, young buds were protected from the ethanol and $\mathrm{HgCl}_{2}$ treatments. Third, it can produce more explants per stem as 'Hanyue' produced abundant flowers, and each stem has about 10 buds. As shown in Table 1, explants produced from the mature stem had the lowest contamination rates and highest bud break rates. On the other hand, explants derived from rhizomes had significantly higher contamination and lower bud break rates; this was attributed to the rhizome as an underground organ which is difficult to decontaminate. The lower bud break in the young node explants was probably caused by the following factors: the bud was too young and not well developed for induction, the disinfection resulted injury or the combination of both.

A simple and efficient regeneration system was established for $H$. coronarium. Buds induced from mature node explants cultured on MS medium supplemented with $17.76 \mu \mathrm{M} \mathrm{BA}, 9.1 \mu \mathrm{M}$ TDZ, and $0.05 \mu \mathrm{M}$ NAA were converted to micro-rhizomes in six weeks (Table 2). Culturing micro-rhizomes on MS medium containing 17.76 $\mu \mathrm{M}$ BA, $6.81 \mu \mathrm{M}$ TDZ, and $2.46 \mu \mathrm{M}$ IBA for eight weeks induced $96 \%$ of micro-rhizomes converting to globular-shaped clumps bearing PLBs (Table 3). A piece of the clump cultured on MS medium supplemented with $17.76 \mu \mathrm{M}$ BA and $0.54 \mu \mathrm{M}$ NAA for six weeks resulted in the production of 15.75 adventitious shoots (Table 4). Continuous growth of the shoots produced adventitious roots. Thus, plantlets were easily transplanted into a substrate for acclimatization. 
The survival rate of the plants in the greenhouse was up to $90 \%$. Plants grew vigorously, and there were no off-types from the regenerated plants.

This study, also for the first time, documented that H. coronarium can be regenerated through PLBs. $H$. coronarium has been propagated via in vitro shoot culture [33,39-42], regenerated through indirect somatic embryogenesis [9,35,43], and a recent regeneration method without a specified pathway [36]. There have been no reports on regeneration H. coronarium through PLBs, although PLBs have been identified in non-orchid plants of Anthurium [19], Colocasia [20], Heliconia [21], Lilium [22], Musa [23], Rosa [24], and Syngonium [25]. As far as is known, the ontogeny of PLBs is still unclear, but some general characteristics of PLBs are as follows: (a) PLBs morphologically resemble protocorms of orchid, but those induced from non-orchid plants do not have the bipolar structure as orchid protocorm $[25,29,40,44]$. (b) PLBs are commonly induced from actively growing tissue or organs. As a result, they often appear from a globular-shaped clump $[25,29]$. Unlikely somatic embryos, PLBs have a vascular connection with explants [25,29]. (c) Each PLB can produce a shoot, and roots can simultaneously form from the shoot base $[25,28,45]$; this is unlike shoot organogenesis where shoots are additionally cultured for root induction. (d) Compared to shoot organogenesis, much more shoots with roots (plantlets) are produced through PLBs. (e) Clumps with PLBs can be cut into two to four pieces, and the culture of the piece results in the induction of more PLBs, and the PLBs can produce shoots with roots [27,46]. In the present study, there was no callus in the entire regeneration process. Multiple PLBs appeared from globular clumps (Figure 2F), and further culture of a piece of the clump (Figure 2H) induced 15.75 PLBs per clump piece (Table 4). As a result, the multiplication rate of this protocol could be 63 shoots per mature node explant in a 20-week culture cycle. PLBs developed into adventitious shoots (Figure 2J-N), and adventitious roots were simultaneously produced from the shoot base (Figure 2O). Thus, plantlets regenerated in this study were not via direct shoot organogenesis. There are at least two schools of thought regarding regeneration via PLBs: one considers that PLBs are somatic embryos [16,26], the other believes that regeneration through PLBs is an independent pathway differing from somatic embryogenesis and organogenesis [12,25,28], but it does have some components of both. A recent study showed that PLBs from Phalaenopsis aphrodite do not follow the somatic embryogenesis pattern [28]. Instead, the SHOOT MERISTEMLESS gene plays a role in PLB regeneration. Thus, PLBs differ from somatic embryos. We believe that $H$. coronarium regeneration via PLBs is independent pathway. PLBs induced in this study were not easily separated from explants as PLBs had a vascular connection with the explants. Nevertheless, this study regenerated more than 11,100 plants that grew healthily in the shaded greenhouse, and no morphological variation was observed. Generally, more somalclonal variation occurs when plants are regenerated through the callus phase and when there is an increased duration of culture and increased number of subcultures [11,13,14,47]. This established protocol just avoids these problems as (a) the regenerated plants were derived from the PLB pathway, which had no passage of callus phase; (b) globular clumps were converted from micro-rhizomes, while micro-rhizomes were converted from existing meristem explants of buds; and (c) there was subculture of explants, globular clumps were cut into four pieces, which were cultured for inducing adventitious shoots and roots, and plantlets were transplanted into a shaded greenhouse. However, to confirm the genetic fidelity of the regenerated plants, further evaluation using molecular markers [48] is warranted.

The protocol established in this study is different from those reported on the in vitro culture of $H$. coronarium. In shoot culture, growth regulator combinations include BA with kinetin, BA with NAA, IAA (indole-3-acetic acid) or IBA [34,42,49]; BA with kinetin and TDZ [49]; and BA or TDZ used alone [50]. The number of shoots induced by those protocols were generally low, ranging from two to eight, with the exception of BA, kinetin, and TDZ combination in which 13.2 shoots per rhizome explant were produced [49]. In regeneration studies, 2, 4-dichlorophenoxy acetic acid (2, 4-D) was used for inducing indirect somatic embryogenesis, and BA was used for further growth of somatic embryos [9], shoot numbers varied from 4 to 11. A recent report showed that over 15 adventitious shoots were regenerated per rhizome explants cultured on MS medium supplemented with TDZ only [36]. However, the pathway for the regeneration was not specified. In this study, one of four pieces 
of globular-shaped clump produced 15.75 shoots. Thus, this represents the efficiency of PLB-mediated regeneration. Moreover, it is worth pointing out the conversions of induced buds to micro-rhizomes and micro-rhizome to PLBs (Tables 2 and 3). The conversions may imply that the induced buds were reversed back to the morphology of rhizomes, whereas the rhizomes to PLBs could largely be due to the action of administered growth regulators. Ogura-Tsyhuta et al. [51] reported interconversion between rhizomes and PLBs during in vitro culture of Cymbidium. In this study, we only observed one-way conversion. Another reported conversion is in the work with Rosa spp. Rhizoids were induced from leaf-derived calluses [24], and TDZ application affected the level of endogenous auxins and cytokinins, changed the cell fate of rhizoid tips, and triggered PLB formation and plantlet regeneration [52]. In another non-orchid plant, nodal explants of S. podophyllum were cultured on MS in the presence of $2.26 \mu \mathrm{M}$ 2,4-D, addition of $8.07 \mu \mathrm{M} \mathrm{N}$-(2-chloro-4-pyridyl)- $\mathrm{N}^{\prime}$-phenylurea (CPPU), $8.88 \mu \mathrm{M}$ BA, $9.84 \mu \mathrm{M}$ N-isopentenylaminopurine (2iP), and 9.08 $\mu \mathrm{M}$ TDZ induced 28.6\%, 39.3\%, 67.9\%, and $71.9 \%$ nodal explants to produce PLBs, respectively [25]. TDZ is a synthetic phenyl urea derivative and has strong cytokinin-like activity exceeding most other commonly used adenine-type cytokinins in regulating plant morphogenesis [12]. Thus, TDZ in induction of PLBs in ginger family plants and monocot plants in general $[25,33,36,53]$ deserves further investigation.

\section{Conclusions}

This is the first documentation that asserts that the flower stem of H. coronarium is a true stem, the node of the stem is the most suitable source for producing explant for in vitro culture, and culturing the node explants induced bud break and the conversion of buds to micro-rhizomes. The culture of micro-rhizome results in the formation of a globular-shaped clump bearing PLBs. The PLBs developed into adventitious shoots with roots. More than 15 adventitious shoots with roots were produced from a small piece of clump. The plantlets were readily transplanted to a substrate for acclimatization. The survival rates of the transplanted plantlets were up to $90 \%$. Thus, the established PLB pathway should represent a new way of in vitro propagation of $H$. coronarium. It is anticipated that the discovery of the true stem could simplify the in vitro propagation of plants in the family Zingiberaceae, and the PLB pathway could accelerate the propagation of disease-free H. coronarium plantlets for conservation or commercial production.

Author Contributions: Conceptualization, X.H. and J.C.; methodology, X.H.; software, J.T.; validation, X.H., J.T., J.C., Y.L.; formal analysis, X.H.; investigation, J.H.; resources, Y.L.; data curation, X.H.; writing-original draft preparation, X.H.; writing-review and editing, J.H., J.C.; visualization, J.C.; supervision, J.C.; project administration, Y.L.; funding acquisition, Y.L. All authors have read and agreed to the published version of the manuscript.

Funding: This research was funded by Forestry Scientific Technology Innovation Project of Guangdong Province with a grant number 2020KJCX010 and the Science and Technology Industry and Information Technology Bureau of Yuexiu District, Guangzhou City with a grant number 2019-GX-007.

Acknowledgments: The authors would like to thank Songjun Zeng from South China Botanic Garden for advice on preparing this manuscript and Terri A. Mellich for critical review of this manuscript.

Conflicts of Interest: The authors declare no conflict of interest.

\section{References}

1. Wu, D.; Kai, L. Zingiberaceae. In Flora of China; Wu, Z., Raven, P., Eds.; Science Press: Beijing, China; Missouri Botanical: St. Louis, MO, USA, 2000; Volume 24, pp. 322-377.

2. Kunnumakkara, A.B.; Ichikawa, H.; Anand, P.; Mohankumar, C.J.; Hema, P.S.; Nair, M.S.; Aggarwal, B.B.; Coronarin, D. A labdane diterpene, inhibits both constitutive and inducible nuclear factor- $\mathrm{kB}$ pathway activation, leading to potentiation of apoptosis, inhibition of invasion, and suppression of osteoclastogenesis. Mol. Cancer Ther. 2008, 7, 3306-3317. [CrossRef]

3. Chen, J.; McConnell, D.B.; Norman, D.L.; Henny, R.J. The foliage plant industry. Hort. Rev. 2005, 31, 47-112.

4. Hartati, R.; Suganda, A.G.; Fidrianny, I. Botanical, phytochemical and pharmacological properties of Hedychium (Zingiberaceae)-A review. Procedia Chem. 2014, 13, 150-163. [CrossRef] 
5. He, E. Study on Hedychium coronarium Koenig's edibility and its pharmacological experiments. Lishizhen Med. Res. 2000, 11, 1077-1078.

6. Gao, L.; Liu, N.; Huang, B.; Hu, X. Phylogenetic analysis and genetic mapping of Chinese Hedychium using SRAP markers. Sci. Hortic. 2008, 117, 369-377. [CrossRef]

7. Pachurekar, P.; Dixit, A. A review on pharmacognostical phytochemical and ethnomedicinal properties of Hedychium Coronarium J. Koenig an endangered medicine. Int. J. Chin. Med. 2017, 1, 49-61.

8. Biswal, A.; Nair, M. Threatened plants of Orissa and priority species for conservation. In Special Habitats and Threatened Plants of India; Rawat, G., Ed.; ENVIS Bulletin, Wildlife Institute of India, Dehradun: Dehradun, India, 2008; Volume 11, pp. 175-186.

9. Verma, M.; Bansal, Y.K. Induction of somatic embryogenesis in endangered butterfly ginger Hedychium coronarium J. Koenig. Indian J. Exp. Biol. 2012, 50, 904-909. [PubMed]

10. Murashige, T. Plant propagation through issue cultures. Annu. Rev. Plant Physiol. 1974, 25, $135-166$. [CrossRef]

11. George, E.F.; Hall, M.A.; De Klerk, G.J. Plant Propagation by Tissue Culture, 3rd ed.; Springer: Dordrecht, The Netherlands, 2008; Volume 1, pp. 29-64.

12. Chen, J.; Wei, X. Thidiazuron in micropropagation of aroid plants. In Thidiazuron: From Urea Derivative to Plant Growth Regulator; Ahmad, N., Faisal, M., Eds.; Springer: Singapore, 2018; pp. 95-113.

13. Kane, M.E. Propagation from preexisting meristems. In Plant Tissue Culture Concepts and Laboratory Exercises; Trigiano, R.N., Gray, D.J., Eds.; CRC Press: New York, NY, USA, 1996; pp. 61-71.

14. Chen, J.; Henny, R.J. Somaclonal variation: An important source for cultivar development of floriculture crops. In Floriculture, Ornamental and Plant Biotechnology II; Da Silva, J.A.T., Ed.; Global Science Books: London, UK, 2006; pp. 244-253.

15. Shenoy, V.; Vasil, I. Biochemical and molecular analysis of plants derived from embryogenic tissue cultures of napier grass (Pennisetum purpureum K. Schum). Theor. Appl. Genet. 1992, 83, 947-952. [CrossRef]

16. Cardoso, J.C.; Zanello, C.A.; Chen, J.T. An overview of orchid protocorm-like bodies: Mass propagation, biotechnology, molecular aspects, and breeding. Int. J. Mol. Sci. 2020, 21, 985. [CrossRef]

17. Morel, G. Producing virus-free cymbidiums. Am. Orchid Soc. Bull. 1960, 29, 495-497.

18. Ishii, Y.; Takamura, T.; Goi, M.; Tanaka, M. Callus induction and somatic embryogenesis of Phalaenopsis. Plant Cell Rep. 1998, 12, 154-159. [CrossRef] [PubMed]

19. Yu, Y.; Liu, L.; Liu, J.; Wang, J. Plant Regeneration by callus-mediated protocorm-like body induction of Anthurium andraeanum. Hort. Agric. Sci. China 2009, 8, 572-577. [CrossRef]

20. Abo El-Ni, M.; Zettler, F. Callus initiation and organ differentiation from shoot tip cultured of Colocasia esculenta. Plant Sci. Lett. 1976, 6, 401-408. [CrossRef]

21. Goh, C.J.; Nathan, M.J.; Kumar, P.P. Direct organogenesis and induction of morphogenic callus through thin section culture of Heliconia psittacorum. Sci. Hortic. 1995, 62, 113-120. [CrossRef]

22. Nhut, D.T.; Le, B.V.; Thanh Van, K.T. Manipulation of the morphogenetic pathways of Lilium longiflorum transverse thin cell layer explants by auxin and cytokinin. Vitro Cell. Dev. Biol.-Plant 2001, 37, 44-49. [CrossRef]

23. Venkatachalam, L.; Thimmaraju, R.; Sreedhar, R.V.; Bhagyalakshmi, N. Direct shoot and cormlet regeneration from leaf explants of 'Silk' banana (AAB). Vitro Cell. Dev. Biol.-Plant 2006, 42, 262-269. [CrossRef]

24. Tian, C.; Chen, Y.; Zhao, X.; Zhao, L. Plant regeneration through protocorm-like bodies induced from rhizoids using leaf explants of Rosa spp. Plant Cell Rep. 2008, 27, 823-831. [CrossRef]

25. Cui, J.; Liu, J.; Deng, M.; Chen, J.; Henny, R.J. Plant regeneration through protocorm-like bodies induced from nodal explants of Syngonium podophyllum 'White Butterfly'. HortScience 2008, 43, 2129-2133. [CrossRef]

26. Lee, Y.I.; Hsu, S.T.; Yeung, E.C. Orchid protocorm like bodies are somatic embryos. Am. J. Bot. 2013, 100, 2121-2131. [CrossRef]

27. Huang, Y.; Tsai, Y.; Cheng, T.; Chen, J.; Chen, F. Physical wounding and ethylene-stimulated embryogenic stem cell proliferation and plantlet regeneration in protocorm-like bodies of Phalaenopsis orchids. Genet. Mol. Res. 2014, 13, 9543-9557. [CrossRef] [PubMed]

28. Fang, S.-C.; Chen, J.-C.; Wei, M.-J. Protocorms and protocorm-like bodies are molecularly distinct from zygotic embryonic tissues in Phalaenopsis aphrodite. Plant Physiol. 2016, 171, 2682-2700. [PubMed] 
29. Gantait, S.; Sinniah, U.R.; Mandal, N.; Das, P.K. Direct induction of protocorm-like bodies from shoot tips, plantlet formation, and clonal fidelity analysis in Anthurium andreanum cv. CanCan. Plant Growth Regul. 2012, 67, 257-270. [CrossRef]

30. Salvi, N.; Geoge, L.; Eapen, S. Direct regeneration of shoots from immature inflorescence cultures of turmeric. Plant Cell Tissue Organ Cult. 2000, 62, 235-238. [CrossRef]

31. Das, A.; Kesar, V.; Rangan, L. Plant regeneration in Curcuma species and assessment of genetic stability of regenerated plants. Biol. Plant. 2010, 54, 423-429. [CrossRef]

32. Sutarno, H.; Hadad, E.; Brink, M. Zingiber officinale Roscoe. In Plant Resources of South-East Asia No.13: Spices; De Guzman, C., Siemonsma, J., Eds.; Backhuys Publishers: Leiden, The Netherlands, 1999; pp. 238-244.

33. Verma, M.; Bansal, Y.K. Effect of a Potent Cytokinin Thidiazuron (TDZ) on in vitro regeneration of Hedychium coronarium J. Koenig-A Valuable Medicinal Plant. Int. J. Rec. Biotech. 2014, 2, 38-44.

34. Mohanty, P.; Behera, S.; Swain, S.S.; Barik, D.P.; Naik, S.K. Micropropagation of Hedychium coronarium J. Koenig through rhizome bud. Physiol. Mol. Biol. Plants 2013, 19, 605-610. [CrossRef]

35. Huang, P.L.; Tsai, C.C. Micropropagation of Hedychium coronarium Koenig. via somatic embryogenesis. J. Chin. Soc. Hortic. Sci. 2002, 48, 239-246.

36. Behera, S.; Kamila, P.K.; Rout, K.K.; Barik, D.P.; Panda, P.C.; Naik, S.K. An efficient plant regeneration protocol of an industrially important plant, Hedychium coronarium J. Koenig and establishment of genetic \& biochemical fidelity of the regenerants. Ind. Crops Prod. 2018, 126, 58-68.

37. Murashige, T.; Skoog, F. A revised medium for rapid growth and bioassay with tobacco tissue culture. Physiol. Plant. 1962, 15, 473-497. [CrossRef]

38. Criley, R.A. Zingiberaceae and Costaceae. In Handbook of Flowering; Halevy, Ed.; CRC Press: Boca Raton, FL, USA, 1985; pp. 542-545.

39. Tripathi, B.K.; Bitaillon, C. In vitro plant regeneration of Hedychium roxburghii Blume through rhizome-meristem culture. Plant Cell Tissue Organ Cult. 1985, 4, 11-17. [CrossRef]

40. Xian, Y.L.; Hu, Y.J.; Chen, S.Z.; Chen, Z.Y. Plant tissue culture and regeneration of Hedychium coccineum. Plant Physiol. Commun. 1989, 43-44.

41. Xiong, Y.H.; Ma, G.H.; Liu, N.; Huang, B.H. In vitro tissue culture and rapid propagation of Hedychium forrestii by seed embroy. Guihaia 2005, 25, 241-244.

42. Bisht, S.; Bisht, N.; Bhandari, S. In vitro plant regeneration from seedling explants of Hedychium coronarium J Koenig. J. Med. Plant Res. 2012, 6, 5546-5551.

43. Tu, H.; Xiao, W.; Deng, C.H. Somatic embryogenesis and plant regeneration of Hedychium coccineum. Acta Hortic. Sin. 2014, 41, 2139-2146.

44. Norstog, K. Embryo culture as a tool in the study of comparative and development morphology. In Plant Cell and Tissue Culture; Sharp, W.R., Ed.; Ohio State University: Columbus, OH, USA, 1979; pp. 179-202.

45. Yeung, E.C. A perspective on orchid seed and protocorm development. Bot. Stud. 2017, 33, 1-14. [CrossRef]

46. Soe, K.; Myint, K.; Naing, A.; Kim, C. Optimization of efficient protocorm-like bodies (PLB) formation of Phalaenopsis and Dendrobium hybrids. Curr. Res. Agric. Life Sci. 2014, 32, 179-183. [CrossRef]

47. Shen, X.; Chen, J.; Kane, M.E.; Henny, R.J. Assessment of somaclonal variation of Dieffenbachia plants regenerated via indirect shoot organogenesis from leaf explants. Plant Cell, Tissue Organ Cult. 2007, 91, 21-27. [CrossRef]

48. Chen, J.; Henny, R.J.; Devenand, P.S.; Chao, C.T. AFLP analysis of nephthytis (Syngonium podophyllum Schott) selected from somaclonal variants. Plant Cell Rep. 2006, 24, 743-749. [CrossRef]

49. Parida, R.; Mohanty, S.; Nayak, S. In vitro propagation of Hedychium coronarium Koen. through axillary bud proliferation. Plant Biosyst. 2013, 147, 905-912. [CrossRef]

50. Rungjindamai, C.; Chenboonngarm, K. Micropropagation of Hedychium coronarium. Acta Hortic. 2014, 1025, 223-229. [CrossRef]

51. Ogura-Tsujita, Y.; Tatsumi, A.; Hayashida, S.; Okubo, H. Interconversion between protocorm-like-bodies (PLBs) and rhizomes in Cymbidium. Fac. Agric. Kyushu Univ. 2007, 52, 325-330. 
52. Kou, Y.; Yuan, C.; Zhao, Q.; Liu, G.; Nie, J.; Ma, Z.; Cheng, C.; Teixeira da Silva, J.A.; Zhao, L. Thidiazuron triggers morphogenesis in Rosa canina L. protocorm-like bodies by changing incipient cell fate. Front. Plant Sci. 2016, 7, 557. [CrossRef] [PubMed]

53. Qu, L.; Chen, J.; Henny, R.J.; Huang, Y.; Caldwell, R.D.; Robinson, C.A. Thidiazuron promotes adventitious shoot regeneration from pothos (Epipremnum aureum) leaf and petiole explants. Vitro Cell. Dev. Biol.-Plant 2002, 38, 268-271. [CrossRef]

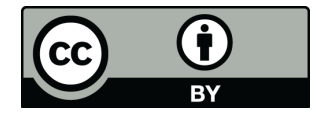

(C) 2020 by the authors. Licensee MDPI, Basel, Switzerland. This article is an open access article distributed under the terms and conditions of the Creative Commons Attribution (CC BY) license (http://creativecommons.org/licenses/by/4.0/). 